\title{
LAJU INFEKSI PENYAKIT WHITE PLAGUE DAN WHITE BAND DISEASE DI PERAIRAN PULAU TIKUS, KOTA BENGKULU
}

\section{Dewi Purnama ${ }^{1}$, Aradea Bujana Kusuma ${ }^{2}$, Bertoka Fajar SP Negara ${ }^{1}$, Person Pesona Renta1, Mulstory Wander Simarmata1, Fanni Alvianto Simanjorang ${ }^{1}$}

\author{
1) Program Studi IImu Kelautan, Fakultas Pertanian, Universitas Bengkulu, \\ Bengkulu, Indonesia \\ 2) Jurusan IImu Kelautan, Fakultas Perikanan dan IImu Kleautan, \\ Universitas Papua, Manokwari, Indonesia \\ E-mail :dewilaut13@gmail.com
}

\begin{abstract}
ABSTRAK
Penyakit karang adalah gangguan terhadap kesehatan karang yang menyebabkan gangguan secara fisiologis bagi biota karang. Penyakit karang dapat memberikan dampak buruk terhadap proses pertumbuhan karang hingga dapat menyebabkan kematian karang disuatu perairan. Dampak dari penyakit karang terhadap ekosistem terumbu karang sangat besar, selain mengakibatkan kematian karang dalam skala yang luas, penyakit karang juga berdampak pada berkurangnya tingkat keanekaragaman sumberdaya alam. Penelitian ini bertujuan untuk mengetahui dan menganalisis laju infeksi penyakit White Plague dan White Band Disease di perairan Pulau Tikus, Kota Bengkulu. Penelitian ini dilaksanakan pada bulan September-Oktober 2019 di Perairan Pulau Tikus, Kota Bengkulu. Metode yang digunakan dalam penelitian ini adalah metode survei, pengamatan dan pengukuran langsung di Lapangan. Hasil Penelitian ini didapatkan bentuk pertumbuhan yang terinfeksi penyakit White Plague di Perairan Pulau Tikus Kota Bengkulu adalah bentuk pertumbuhan karang Massive dan penyakit White Band Disease pada karang Acropora. Metode yang digunakan dalam penelitian ini adalah metode survei, pengamatan dan pengukuran langsung di lapangan.Laju infeksi penyakit White Plague di perairan Pulau Tikus Kota Bengkulu adalah 0,009 - 0,023 cm/hari. Laju infeksi penyakit White Plague mengalami kenaikan setiap minggu dengan rata rata laju infeksi $0,015 \mathrm{~cm} / \mathrm{hari}$ dan nilai laju infeksi penyakit White Band Disease yang terdapat pada karang Acropora di Perairan Pulau Tikus, Bengkulu yaitu 0,013 cm/hari - 0,030 $\mathrm{cm} /$ hari. Rata - rata yang diperoleh yaitu $0,024 \mathrm{~cm} /$ hari. Nilai laju infeksi karang menandakan bahwa sebagian besar kerusakan terumbu karang diakibatkan oleh penyakit karang.
\end{abstract}

Kata Kunci : Penyakit Karang, White Plague, White Band Disease, Laju Infeksi 


\begin{abstract}
THE RATE OF WHITE PLAGUE AND WHITE BAND DISEASE IN TIKUS ISLAND, BENGKULU CITY. Coral disease is a disorder of coral health that causes physiological disruption to coral biota. The coral disease can adversely affect the coral growth process until it can lead to coral death in a waterway. The impact of coral disease on coral ecosystems is very large. In addition to resulting in coral death on a wide scale, a coral disease also affects natural resources' reduced diversity. This research aimed to determine and analyze the White Plague and White Band Disease's infection rate in Tikus Island, Bengkulu City. The research was conducted in September-October 2019, located in Tikus Island Water, Bengkulu City. The methods used in this study are direct survey, observation, and measurement methods in the Field. This study obtained a form of growth infected with White Plague disease in the Waters of Tikus Island Bengkulu City. The infection rate of White Plague Disease in Tikus Island was 0.009$0.023 \mathrm{~cm} /$ day. The quality of the condition of White Plague disease increased every week with an average infection rate of $0.015 \mathrm{~cm} /$ day, and the rate of infection rate of White Band Disease found in Acropora coral in the Waters of Tikus Island, Bengkulu which was $0.013 \mathrm{~cm} /$ day -0.030 $\mathrm{cm} /$ day. The average obtained $0.024 \mathrm{~cm} /$ day. The coral infection rate indicates that most of the damage to coral reefs was caused by coral disease.
\end{abstract}

Keywords : Coral Disease, White Plague, White Band Disease, Infection Rate

\title{
PENDAHULUAN
}

Ekosistem terumbu karang adalah ekosistem yang hidup di dasar perairan laut dangkal di daerah tropis dan subtropis yang dibentuk oleh kegiatan biologis dari hewan hewan karang Anthozoa. Karang adalah hewan tak bertulang belakang yang termasuk dalam Filum Coelenterata (hewan berongga) atau Cnidaria, berbentuk tabung, memiliki mulut yang dikelilingi oleh tentakel. Karang mencakup Ordo Scleractinia dan Sub kelas Octocorallia (kelas Anthozoa) maupun kelas Hydrozoa (Veron, 2000).

Terumbu karang memiliki fungsi yang sangat penting baik secara ekologis, fisik maupun ekonomis. Secara ekologis, terumbu karang menjadi tempat tinggal, berkembang biak dan mencari makan bagi ribuan jenis ikan dan hewan yang hidup di laut. Selain itu juga terumbu karang juga sebagai daerah asuhan bagi biota laut dan sebagai sumber plasma nutfah dilautan (Santoso dan Kardono, 2008). Secara ekonomis terumbu karang merupakan habitat bagi hewan-hewan yang memiliki nilai ekonomis yang tinggi, seperti ikan kerapu, lobster, dan ikan napoleon (Malay, 2000). Manfaat fisik terumbu karang yaitu melindungi ekosistem pesisir dan pantai dari erosi gelombang dan badai, melindungi pelabuhan dan pantai dari hantaman ombak (Riyantini, 2008). 
Kondisi terumbu karang sudah semakin terdegradasi akibat kerusakan pada terumbu karang. Menurut Harrison dkk. (2011) Kerusakan yang terjadi pada terumbu karang diakibatkan oleh aktivitas manusia seperti kegiatan wisata dan adanya penggunaan alat tangkap yang tidak ramah lingkungan. Aktivitas tersebut dapat menimbulkan dampak negatif bagi kehidupan terumbu karang yang ditandai dengan perubahan warna yang berdampak pada kematian karang. Selain aktivitas manusia, kerusakan terumbu karang juga dapat disebabkan oleh faktor lingkungan dimana salah satunya adalah penyakit karang. Polusi sampah laut seperti sampah plastik, logam, kaca, dan kertas diduga sebagai penyalur terhadap penyakit terumbu karang. Penyakit karang (coral disease) diduga sebagai penyebab utama terdegradasinya karang. Penyakit karang merupakan sumber kerusakan yang dapat menghambat laju pertumbuhan dan menyebabkan kematian pada populasi karang (Renta dkk., 2020).

Stedman (2000), menjelaskan penyakit sebagai segala yang merusak (gangguan, gencatan, perkembangbiakan atau kekacauan lainnya) dari fungsi penting tubuh, sistem atau organ. Penyakit karang adalah gangguan terhadap kesehatan karang yang menyebabkan gangguan secara fisiologis bagi biota karang (Raymundo dan Harvell, 2008).

Munculnya penyakit karang dicirikan dengan adanya perubahan warna, kerusakan dari skeleton biota karang, sampai dengan kehilangan jaringannya. Beberapa faktor lingkungan penyebab terjadi penyakit karang di antaranya adalah faktor abiotik seperti kenaikan temperatur, sedimentasi, sinar ultraviolet, logam berat, dan bahan kimia dari kegiatan budidaya. Sementara dari faktor biotik seperti bakteri, virus, jamur, atau protozoa dan juga karena cacing dan arthropoda (Yamashiro, 2004). Koloni bentuk pertumbuhan yang paling banyak terserang penyakit karang dan gangguan kesehatan yaitu jenis koloni bentuk pertumbuhan Coral Massive 444 koloni bentuk pertumbuhan.

Dampak dari penyakit karang terhadap ekosistem terumbu karang sangat besar, selain mengakibatkan kematian karang dalam skala yang luas, penyakit karang juga berdampak pada berkurangnya tingkat keanekaragaman sumberdaya alam. Selain berdampak terhadap ekologi, penyakit terumbu karang juga berdampak langsung terhadap perekonomian nelayan khususnya didaerah pesisir dikarenakan berkurangnya ikan ekonomis penting (Rani, 2003).

Penyakit White Plague dan penyakit White Band Disease merupakan jenis penyakit yang sering menginfeksi karang dimana penyakit White Plague merupakan salah satu penyakit yang menghilangkan jaringan yang cepat yang mempengaruhi banyak spesies karang. White Plague menyerang karang jenis massive dan encrusting yang diamati terlihat adanya jaringan karang yang hilang, meninggalkan rangka karang yang berwarna putih kosong (Richardson, 1998) dan White Band Disease yaitu penyakit ditandai dengan linier, band yang terjadi karena karang kehilangan jaringan dengan lebar $2-10 \mathrm{~cm}$ yang dapat membatasi cabang, band memisahkan jaringan sehat dari kerangka yang terkena epibiont, penyakit dapat berkembang cepat $(\mathrm{mm}-\mathrm{cm} /$ hari) dari dasar koloni atau bifurkasi cabang, dan hanya diamati pada Acropora (Raymundo et al., 2008). 
Provinsi Bengkulu memiliki beberapa pulau yang mempunyai keanekaragaman terumbu karang, salah satunya yaitu Pulau Tikus. Penelitian yang sudah pernah dilakukan di Pulau Tikus yang terkait karang yaitu ekowisata terumbu karang, tutupan karang, ikan karang, dan lain-lain.

Pulau Tikus sendiri memiliki rataan terumbu karang yang luas. Perairannya relatif jernih dengan dasar perairan berupa pasir, pecahan karang mati, dan karang mati yang telah ditumbuhi oleh alga. Namun keberadaan terumbu karang di Pulau Tikus sudah lama mengalami degradasi karena adanya pengerusakan baik itu oleh manusia maupun penyakit terumbu karang (Bakhtiar, 2013).Berdasarkan Penelitian yang telah dilakukan oleh Rosenberg et al. (2005) mengenai bakteri strain BA-3 dan faktor yang dapat menyebabkan penyakit White Plague di karang eilat yang menyebutkan bahwa infeksi penyakit White Plague adalah menular dan laju infeksi White Plague yaitu 0,02-0,01 cm/hari. Penelitian tentang penyakit karang juga pernah dilakukan oleh Mellani (2019), tentang infeksi karang White Plague di Perairan Jemeluk dan Penutukan-Bali. Sedangkan saat ini penelitian tersebut belum pernah dilakukan di Perairan Pulau Tikus, Kota Bengkulu. Penelitian ini bertujuan untuk mengetahui dan menganalisis laju infeksi penyakit White Plaguedan White Band Disease di perairan Pulau Tikus, Kota Bengkulu.

\section{MATERI DAN METODE}

\section{Waktu dan Tempat}

Penelitian ini dilaksanakan pada bulan September-Oktober 2019, yang berlokasi diperairan Pulau Tikus, Kota Bengkulu.

\section{Metode Penelitian}

Metode yang digunakan dalam penelitian ini adalah metode survei, pengamatan dan pengukuran langsung dilapangan. Data yang diperoleh dianalisa menggunakan metode deskriptif.

\section{Prosedur Pengambilan Data}

\section{Tahap Persiapan}

Tahap persiapan ini dilakukan untuk mengetahui informasi mengenai kondisi awal dan karakteristik lokasi penelitian yang akan dijadikan sebagai acuan dalam pengambilan data laju infeksi penyakit karang dan juga dalam mempersiapkan alat dan bahan yang akan digunakan saat penelitian.

\section{Penetapan Lokasi Penelitian}

Penetapan lokasi penelitian dilakukan berdasarkan hasil yang diperoleh dari informasi yang dikumpulkan pada tahap persiapan yaitu berupa karakteristik dan kondisi lokasi penelitian, selain itu penetapan 
lokasi penelitian ini juga dilihat dari keberadaan koloni karang yang ada diperairan. Lokasi penelitian berada di perairan Pulau Tikus, Kota Bengkulu dengan kedalaman 1-2 meter. Penentuan titik koordinat lokasi penelitian dilakukan menggunakan GPS dimana ini dilakukan untuk mengetahui letak lokasi penelitian sacara geografis.

\section{Penyakit Karang}

Pengamatan terhadap penyakit karang dilakukan dengan pengambilan gambar karang yang terinfeksi penyakit secara visual dengan menggunakan kamera bawah air kemudian diidentifikasi sesuai petunjuk identifikasi penyakit karang yakniCoral Disease Handbook Guidelines for Assessment, Monitoring \& Management (Raymundo et al., 2008).

\section{Jenis Karang}

Pengamatan Jenis karang yang terinfeksi penyakit diidentifikasi dengan hasil pengambilan gambar secara visual menggunakan kamera bawah air lalu dikonfirmasi sesuai petunjuk identifikasi bentuk pertumbuhan karang dari petunjuk buku jenis jenis karang di Indonesia edisi ke-3 (Suharsono, 2008) dan buku yang berjudul Coral of the word volume 1-3 (Veron, 2000) dimana buku ini digunakan untuk mengidentifikasi karang tingkat genus.

\section{Laju Infeksi Penyakit}

Pengukuran laju infeksi karang menggunakan alat jangka sorong. Karang yang terinfeksi penyakit dipilih dan ditandai dengan menancapkan paku pada bagian karang massive yang sudah terinfeksi penyakit lalu mengikatkan kabel ties pada bagian paku yang sudah tertancap dan bagian yang sudah terinfeksi diukur dari jarak yang terjauh, jarak sedang dan jarak terdekat.

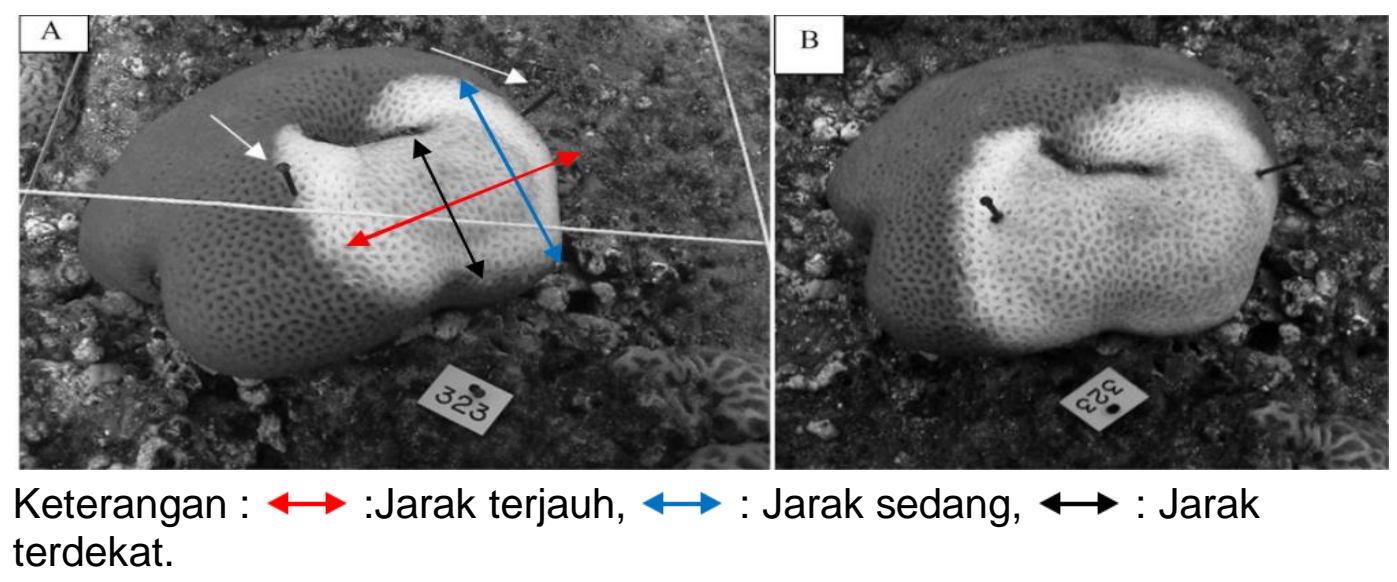

Gambar 1. Pengukuran laju infeksi White Plague pada karang massive (Rosenberg et al., 2005) 
Karang Acropora ditandai dengan mengikatkan kabel ties pada bagian karang yang terinfeksi penyakit lalu diukur dari pangkal hingga ke jarak terjauh. Pengkuran laju infeksi karang dilakukan setiap satu minggu sekali selama rentan waktu empat minggu dengan menggunakan jangka sorong $(0,02 \mathrm{~mm})$, pengukuran laju infeksi penyakit disajikan dalam Gambar 2.
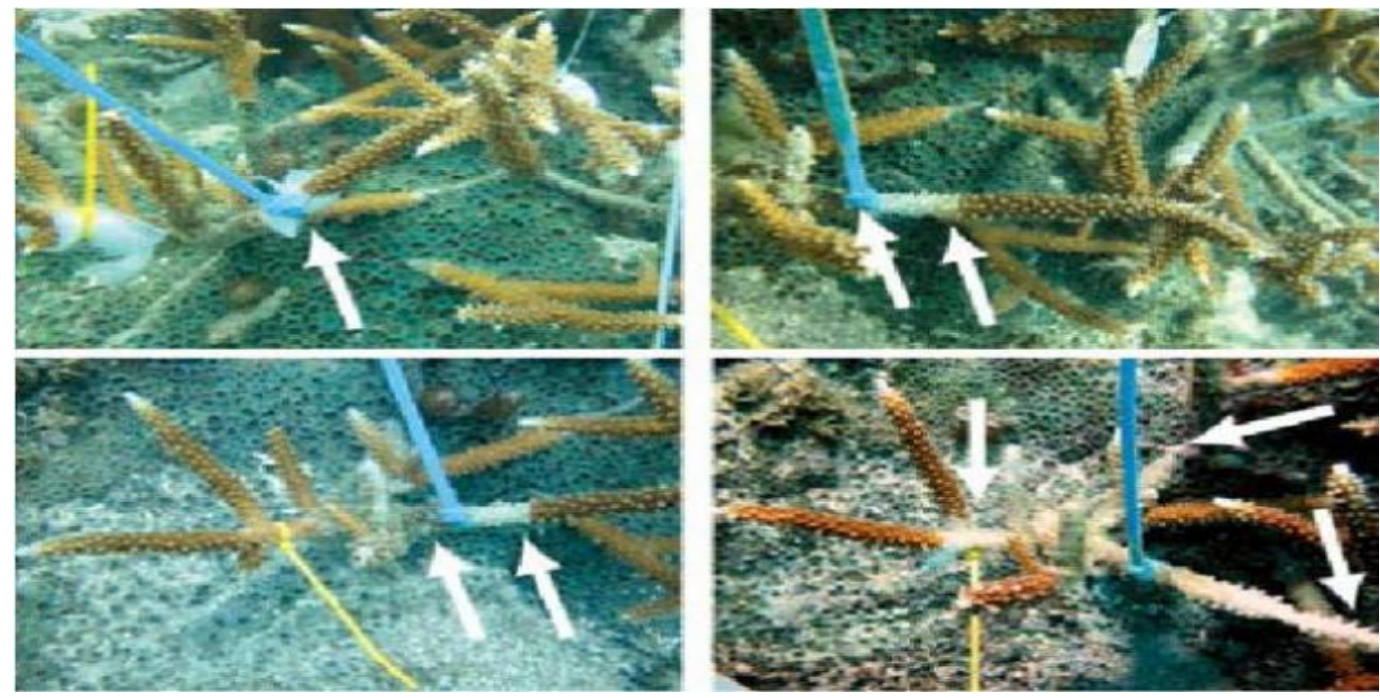

Gambar 2. Pengukuran laju infeksi White Band Disease pada karang Acropora

\section{Parameter Perairan}

Parameter perairan yang diukur adalah suhu, salinitas, arus, kecerahan, $\mathrm{pH}$. Dalam pengukuran suhu digunakan alat thermometer dengan cara di celupkan kedalam perairan dan didiamkan kurang lebih 5 menit. Setelah itu diangkat dan diamati perubahan skala pada thermometer. Salinitas diukur dengan menggunakan refraktometer, dengan meneteskan satu tetes air laut pada prisma refraktometer, kemudian melihat angka yang terera di bagian eyepiece. Arus diukur dengan menggunakan bola duga yang diberi tali 7 meter kemudian di lepas di perairan dan dihitung dengan stopwatch. Kecerahan dengan menggunakan secchi disk dengan cara menurunkan alat tersebut kedalam perairan dengan mengukur jarak tampak dan tidak tampak. $\mathrm{pH}$ diukur dengan menggunakan $\mathrm{pH}$ meter dengan cara mencelupkan $\mathrm{pH}$ meter ke dalam air kemudian melihat angka yang tertera pada $\mathrm{pH}$ meter. Pengukuran parameter perairan ini dilakukan satu kali dalam seminggu di lokasi penelitian.

\section{Analisis Data}

\section{Laju Infeksi Penyakit White Plague}

Pengukuran laju infeksi penyakit dilakukan dengan cara manual dengan jangka sorong. Karang yang terinfeksi penyakit dipilih dan ditandai 
dengan mengikatkan kabel ties dan diukur dari yang terjauh. Pengukuran laju infeksi karang dilakukan setiap satu minggu sekali selama empat minggu dengan menggunakan jangka sorong $(0,02 \mathrm{~mm})$. Selanjutnya penghitungan laju infeksi penyakit karang dihitung menggunakan rumus (Raymundo et al., 2008).

$$
\text { Laju Infeksi }=\frac{\text { jarak dari kabel tis ke garis depan penyakit }(\mathrm{cm})}{\text { Satuan waktu }}
$$

\section{Parameter Perairan}

Parameter perairan diambil secara in situ. Parameter in situ adalah yang diamati pada saat pengambilan sampel di lapangan. Parameter perairan disajikan dalam bentuk tabulasi dan disajikan dengan metode deskriptif, tujuannya adalah untuk mempelajari keterkaitan antara parameter perairan dengan penyakit karang.

\section{HASIL DAN PEMBAHASAN}

\section{Laju Infeksi Penyakit}

Laju infeksi penyakit merupakan kecepatan infeksi penyakit yang menyerang jaringan. Infeksi merupakan masuknya mikroorganisme atau mikroba pathogen yang memperbanyak diri di dalam jaringan tubuh yang menyebabkan peradangan atau kerusakan pada jaringan tubuh (Gaillard, 2012) sedangkan menurut potter dan Perry (2005), Infeksi adalah proses invasif oleh mikroorganisme dan berproliferasi didalam tubuh yang menyebabkan sakit. Secara umum proses terjadinya penyakit melibatkan tiga faktor yang saling berinteraksi yaitu: faktor penyebab penyakit (agen), faktor manusia atau penjamu (host), dan faktor lingkungan (Mazni, 2008). Infeksi penyakit karang umumnya terjadi ketika karang mengalami stress akibat tekanan dari lingkungan, seperti pencemaran, suhu tinggi, sedimentasi, nutrient yang tinggi terutama nitrogen dan senyawa carbon, predator, kompetisi dengan alga yang pertumbuhannya sangat cepat, dan kondisi fisiologis yang lemah setelah terjadi pemutihan (Antonius and Lipscomb, 2001; Raymundo et al., 2008).

Hasil pengukuran laju infeksi penyakit White Plague pada karang massive yang disajikan pada Gambar 3.

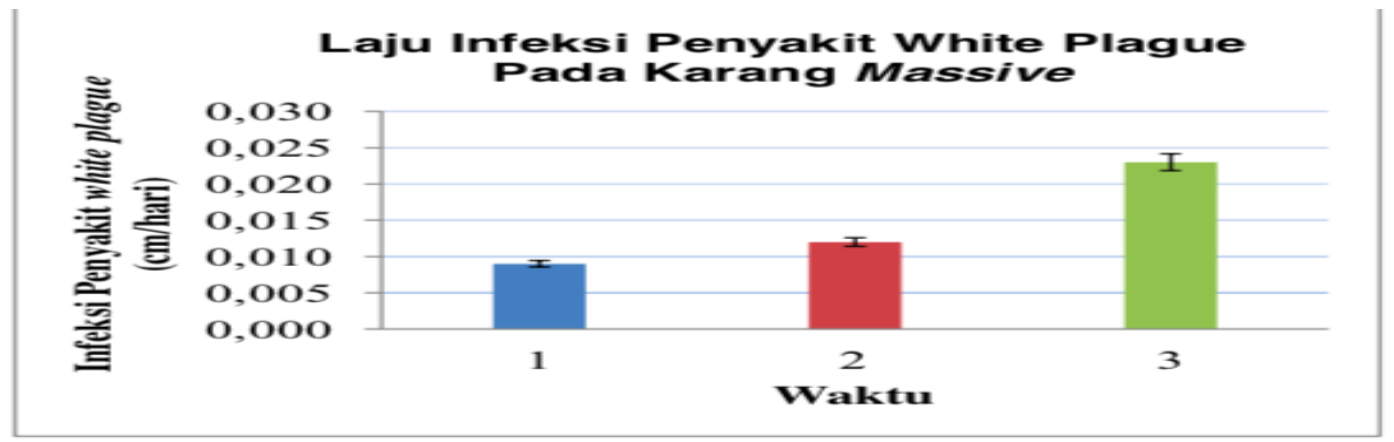

Gambar 3. Grafik laju infeksi penyakit White Plague pada karang massive

DOI: https://doi.org/10.31186/jenggano.5.2.219-232 
Laju infeksi penyakit White Plague rata rata selama pengamatan yaitu 0,009-0,023 cm/hari. Laju infeksi penyakit tersebut mengalami kenaikan setiap minggunya. Laju infeksi tertinggi terdapat pada minggu ketiga yaitu sebesar $0,023 \mathrm{~cm} /$ hari. Hasil dari penelitian yang diperoleh ini hampir sama dengan yang penelitian yang dilakukan oleh Rosenberg et al. (2005) yang menyatakan bahwa infeksi penyakit White Plague itu menular dan laju infeksi White Plague yaitu 0,02-0,01 cm/hari. Dustan (1977) dan Richardson et al. (1998), menyatakan bahwa penyakit White Plague menyebabkan kehilangan jaringan dengan perkembangan paling lambat hanya 0,1-0,4 mm/hari dan berkembang pada kecepatan maksimum 0,2 $\mathrm{cm} /$ hari. Sedangkan Sutherland et al. (2004), Penyebaran penyakit White Plague yang menginfeksi karang dapat meluas pada tingkat rata rata $0,23 \pm 0,12 \mathrm{~cm} /$ hari. Hilangnya jaringan karang yang sangat cepat, mungkin disebabkan oleh bacterium dan dampaknya meluas dari satu koloni ke koloni yang lain (Richardson, et al., 1998).

Hasil penelitian yang diperoleh menunjukkan bahwa penyakit White Plague yang menginfeksi karang massive di Pulau Tikus Kota Bengkulu termasuk jenis penyakit White Plague Tipe I dimana ini sesuai menurut Atad et al. (1990), bahwa Tipe I, varietas yang diidentifikasi pada tahun 1977, menyebabkan kematian jaringan karang pada tingkat sekitar 1/10 inci (3 milimeter)/hari. White Plague tipe I, dilaporkan mempengaruhi 10 spesies karang dan efeknya menyebabkan jaringan lunak karang mengalami kematian dengan kisaran sekitar $3 \mathrm{~mm} /$ hari (Richardson, 1998).

Penyakit White Plague yang menginfeksi karang di Pulau Tikus ditandai dengan adanya bentuk yang tidak beraturan yang berwarna putih seperti wabah pada bagian karang yang telah kehilangan jaringan. Bagian yang berwarna putih inilah yang merupakan penyakit White Plague.Hal ini sesuai dengan pernyataan Rosyid (2018), bahwa penyakit White Plague menyebabkan bagian karang yang telah kehilangan jaringan terlihat jelas hanya tinggal kerangka dan luka yang diakibatkan penyakit ini terlihat berwarna putih. Menurut Sunagawa (2009), White Plague ditandai oleh hilangnya jaringan yang cepat, yang memperlihatkan kerangka putih karang.Penyakit White Plague di sebabkan oleh bakteri yang menyerang karang yang imunya rendah. Jenis bakteri yang menyerang White Plague yaitu Protobacteria, Sphingomonoas sp. dan Aurantimonas Corallicida. Karang yang terifeksi penyakit White Plague disajikan dalam Gambar 4.

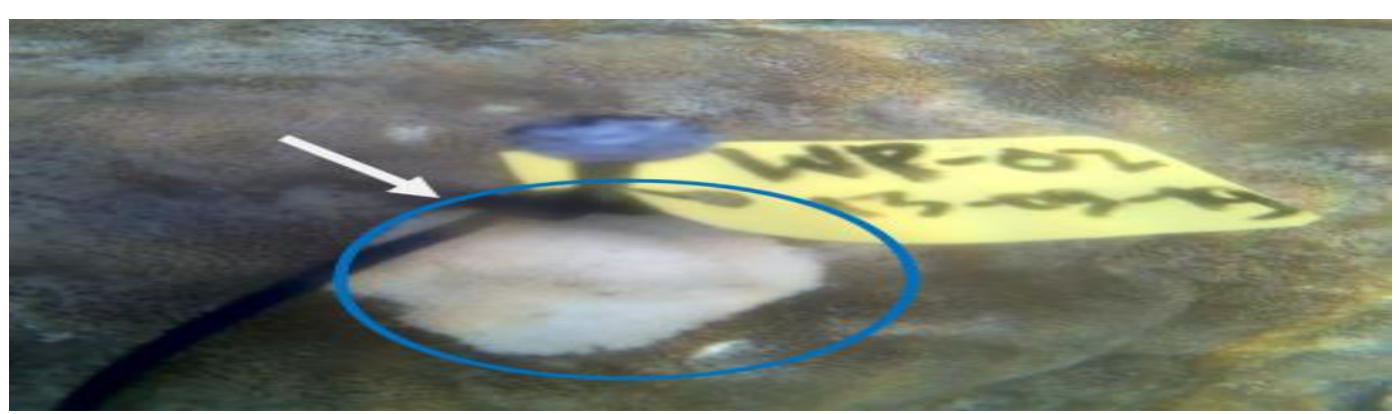

Gambar 4. Coral massive yang terinfeksi penyakit White Plague 
Pengukuran laju infeksi penyakit White Band Disease yang menginfeksi karang Acropora dimana Pengukuran laju infeksi penyakit White Band Disease diukur dari pangkal sampai ujung batang karang Acropora yang terkena infeksi dengan menggunakan jangka sorong $(0,02$ $\mathrm{mm}$ ) yang diukur sekali seminggu selama empat minggu. Berdasarkan hasil penelitian yang dilakukan di Perairan Pulau Tikus, Bengkulu dengan pengukuran secara manual mulai minggu pertama hingga minggu keempat yaitu diperoleh bahwa nilai laju infeksi White Band Disease pada karang Acropora berkisar $0,013 \mathrm{~cm} /$ hari $-0,030 \mathrm{~cm} /$ hari. Rata - rata laju infeksi yang diperoleh yaitu $0,024 \mathrm{~cm} /$ hari. Pada minggu kedua t (1) didapatkan hasil $0,013 \mathrm{~cm} /$ hari, laju infeksi pada minggu ketiga $t$ (2) didapatkan hasil $0,030 \mathrm{~cm} /$ hari, sedangkan pada minggu keempat $t$ (3) laju infeksi didapatkan sebesar 0,028 cm/hari. Menurut Galdfelter (1991) pada bagian jaringan Acropora cervicornis, hanya hilang pada pertengahan suatu cabang. Tingkat jaringan karang yang hilang sebesar 1/8 -1/4 inci/hari, dan rangka karang yang kosong segera akan diganti dengan alga berfilamen.

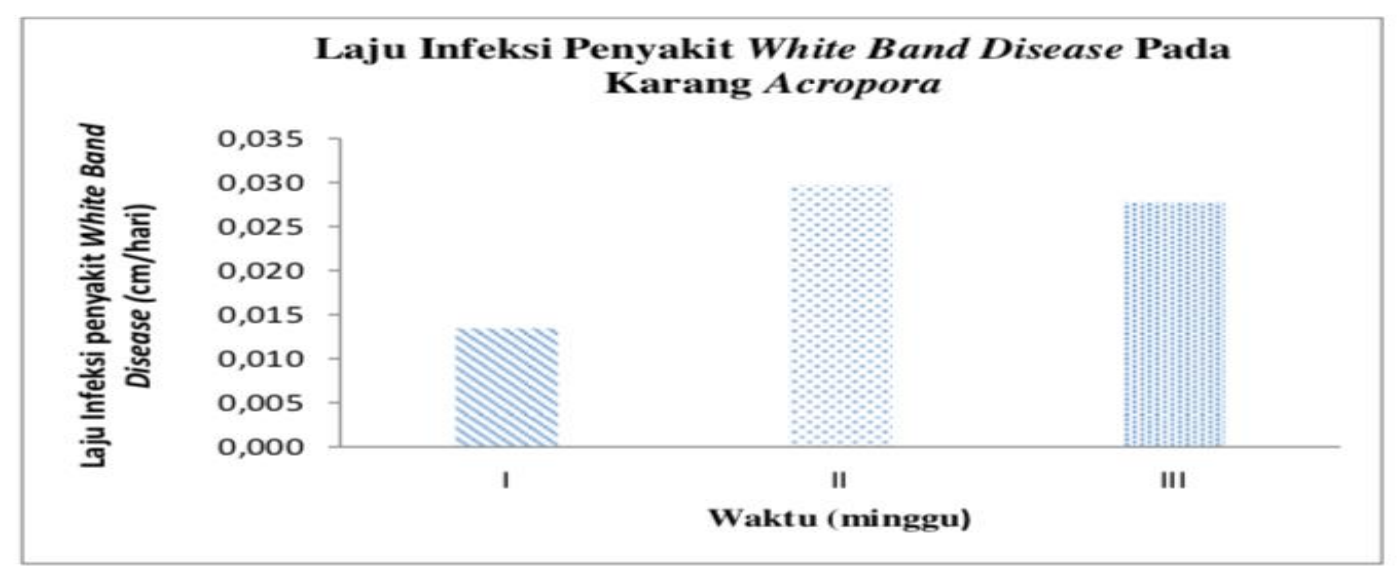

Gambar 5. Laju infeksi penyakit White Band Disease

Penyakit White Band Disease (WBD) yang ditemukan di Perairan Pulau Tikus, Bengkulu dicirikan dengan adanya band berwarna puth melingkar pada percabangan karang Acropora. Infeksi mulai dari pangkal batang menuju ujung batang atau jaringan yang sehat, dan jaringan yang sudah mati ditempati oleh alga. Nugraha (2008), melaporkan bahwa Penyakit White Band Disease ditandai dengan adanya band berwarna putih terletak diantara jaringan karang yang sehat dan jaringan karang yang sudah mati. White Band Disease (WBD) juga hanya menyerang pada karang Acropora (Raymundo et al., 2008). Handayani dkk. (2017) melaporkan bahwa kenaikan suhu air laut diduga turut menyebabkan meningkatnya agresivitas dan timbulnya penyakit White Band Disease (WBD) pada karang Acropora. Fajar dkk., (2018) juga melaporkan bahwa Bakteri yang berasosiasi dengan penyakit White Band Disease pada karang Acropora adalah bakteri Vibrio alginolyticus, Vibrio owensii, dan Pseudo alteromonasrubra. 


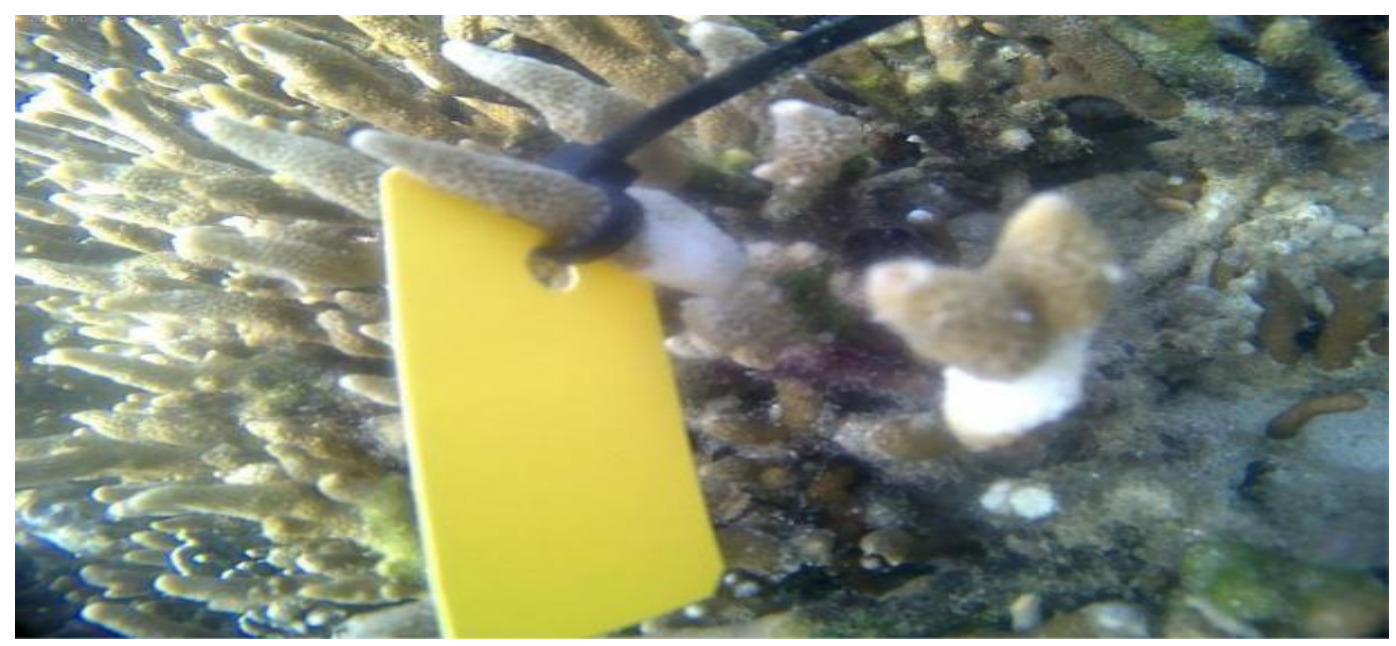

Gambar 6. Acropora sp. yang terkena White Band Disease di Pulau Tikus, Bengkulu

\section{Parameter Perairan}

Kondisi parameter perairan menunjukkan bahwa pada lokasi penelitian tidak menunjukkan adanya perbedaan atau variasi kondisi yang sangat berbeda selama penelitian yang dilakukan dalam waktu satu bulan dari bulan September-Oktober 2019. Parameter perairan ini diambil secara insitu dan waktu pengukuran yaitu pada siang. Parameter fisika perairan terdiri dari suhu, kecerahan, dan kecepatan arus, dan parameter kimia perairan yaitu $\mathrm{pH}$ dan salinitas. Kondisi parameter perairan pada lokasi penelitian disajikan pada Tabel 1.

Tabel 1. Parameter perairan pada lokasi penelitian

\begin{tabular}{|c|c|c|c|c|c|c|c|}
\hline \multirow[t]{2}{*}{ No } & \multirow{2}{*}{$\begin{array}{l}\text { Parameter } \\
\text { Perairan }\end{array}$} & \multicolumn{5}{|c|}{ Pengamatan } & \multirow[t]{2}{*}{ Baku Mutu } \\
\hline & & I & II & III & IV & $\begin{array}{l}\text { Rata- } \\
\text { rata }\end{array}$ & \\
\hline \multirow[t]{2}{*}{1} & Suhu $\left({ }^{\circ} \mathrm{C}\right)$ & 27 & 27,17 & 27 & 27,83 & 27,25 & $\begin{array}{l}25-29^{\circ} \mathrm{C} \text { (Eliza, } \\
1992)\end{array}$ \\
\hline & & & & & & & $27-40 \%$ \\
\hline 2 & $\begin{array}{l}\text { Salinitas } \\
(\%)\end{array}$ & 32,67 & 32,67 & 32,33 & 33 & 32,67 & $\begin{array}{l}\text { (Supriharyono, } \\
2007 \text { ) }\end{array}$ \\
\hline 3 & $\operatorname{Arus}(\mathrm{m} / \mathrm{s})$ & 0,28 & 0,26 & 0,27 & 0,25 & 0,27 & - \\
\hline 4 & $\begin{array}{l}\text { Kecerahan } \\
(\%)\end{array}$ & 100 & 100 & 100 & 100 & 100 & - \\
\hline
\end{tabular}


Hasil pengukuran parameter fisika pada lokasi penelitian diperoleh nilai suhu rata - rata pada lokasi penelitian yaitu $27,25^{\circ} \mathrm{C}$ seperti pada tabel 2. Nilai suhu rata rata tersebut menunjukkan bahwa suhu ini adalah normal dan tidak merusak karang karena kisaran suhu ini masih dapat ditoleran oleh terumbu karang untuk proses pertumbuhan terumbu karang. Nybakken (1988), menyatakan bahwa nilai suhu dilapisan permukaan laut yang normal berkisar $20-30^{\circ} \mathrm{C}$, dimana parameter suhu air laut mempunyai toleransi terhadap pertumbuhan karang batu. Kecepatan arus rata rata pada lokasi penelitian yaitu sebesar $0,27 \mathrm{~m} / \mathrm{s}$. Faktor adanya arus yang kuat di suatu perairan dapat menjadi pengantar penyebaran penyakit karang (Johan, 2014). Nilai kecerahan yang diperoleh dari pengukuran yang dilakukan selama penelitian yaitu $100 \%$ dan sama setiap minggunya. Kedalaman perairan lokasi penelitian hanya 1 meter karena setiap pengkuran dilakukan perairan sedang surut yang membuat kecerahan setiap minggunya adalah sama yaitu $100 \%$. Pengukuran parameter kimia pada lokasi penelitian diperoleh nilai rata rata salinitas pada lokasi penelitian yaitu $32,67 \%$. Nilai salinitas tersebut termasuk salinitas normal yang masih dapat ditolerir oleh terumbu karang dimana ini sesuai menurut Eliza (1992), salinitas yang ideal untuk pertumbuhan dan perkembangan karang berkisar antara 25-40\%o. Cahaya yang cukup dapat mendukung kehidupan karang dan tanpa cahaya, laju fotosintesis akan berkurang bersamaan dengan kemampuan karang untuk menghasilkan kalsium karbonat dan membentuk terumbu akan berkurang (Wijaya dkk., 2017).

Hasil pengukuran parameter perairan yang diperoleh pada lokasi penelitian menunjukkan bahwa nilai parameter perairan pada lokasi penelitian adalah normal dan masih dapat ditolerir oleh terumbu karang. Parameter perairan yang pada lokasi penelitian seperti suhu dan salinitas adalah ideal namun laju infeksi penyakit White Plague dan White Band Disease yang menginfeksi karang tetap mengalami peningkatan. Pertambahan laju infeksi setiap minggu mengalami kenaikan. Tingginya laju infeksi ini disebakan oleh bakteri-bakteri yang berasosiasi pada penyakit tersebut. Bakteri - bakteri ini dapat menyebar karena adanya arus dimana Arus dapat menjadi salah satu media penyabaran mikroorganisme patogen yang dapat menimbulkan penyakit karang (Dahuri, 2003).

\section{KESIMPULAN}

Penyakit White Plague di Pulau Tikus, Kota Bengkulu menginfeksi bentuk pertumbuhan karang massive dengan laju infeksi penyakit berkisar antara 0,009-0,023 cm/hari. Laju infeksi penyakit White Plague mengalami kenaikan setiap minggu dengan rata rata laju infeksi $0,015 \mathrm{~cm} / \mathrm{hari}$ dan laju infeksi penyakit White Band Disease (WBD) yang terdapat pada karang Acropora di Perairan Pulau Tikus, Bengkulu yaitu 0,013 cm/hari - 0,030 $\mathrm{cm} /$ hari. Dan rata - rata yang diperoleh yaitu $0,024 \mathrm{~cm} / \mathrm{h}$ ari. 


\section{DAFTAR PUSTAKA}

Antonius, A., Lipscomb, D., 2001. First Protozoan Coral Killer Identified in The Indo-Pacific. Atoll Research Bulletin. 1(21): 481-493.

Atad I, Zvuloni A, Loya Y, Rosenberg E. 1990. Phage therapy of the white plague-like disease of Favia favus in the Red Sea. Coral reefs. 31: 665-670.

Bakhtiar, D. dan Z. Ta'alidin, 2013. Kajian Identifikasi Terhadap Kondisi Pulau Tikus. Pemerintah Provinsi Bengkulu.

Dahuri, R. 2003. Kebijakan dan Strategi Pengelolaan Terumbu Karang Indonesia. Pengelolaan dan Iptek Terumbu Karang Indonesia. Jakarta : $1-16$.

Dustan, P 1977. Vitality of reef coral populations off KeyLargo,Florida: recruitment and mortality. Environ Geol. 2:51-58

Eliza, 1992. Dampak Pariwisata terhadap pertumbuhan terumbu karang. Lingkungan dan Pembangunan. 12(3): 150-170.

Fajar, M. H., Insafitri., M. Efendy., dan W. A. Nugraha. 2018. Karakteristik Penyakit White Band Disease Dan White Syndrome Secara Visual Dan Hitologi Pada Karang Acropora sp. dari Pulau Gili Labak Sumenep Madura. Jurnal ilmu dan teknologi kelautan tropis. 10(3): $711-718$.

Gaillard, J. P. 2012. Enhanced brain delivery of liposomal methylprednisolone improved therapeuticefficacy in a model of neuroinflammation. Journal of Controlled Release. 164: 364-369.

Galdfelter, W.B. 1991. Population Structure of Acropora palmata on the Windward Fore Reef, Buck Island National Monument, St. Croix, U.S. Virgin Islands. U.S. Virgin Islands: U.S. Department of the Interior, National Park Service : 172 pp.

Handayani, M., Semedi, B., Asadi, M. A., Herdiutami, M., Novakandi, R., dan Zakiyah. 2017. Prevalensi Penyakit Karang White Band Disease Di Perairan Malang Selatan, Jawa Timur. Program Studi IImu Kelautan, Universitas Brawijaya Malang.

Harrison, J. P., Sapp, M., Schratzberger, M dan Osborn,A. M. 2011. Interactions between Microorganisms and Marine Microplastics: a call for research. Journal Mar Tech Socie. 45:12-20. 
Johan, O., M. Delpop., S. A. Putra., F. Hadi., R. H. Putri., R. F., dan N. P. Zamani. 2014. Prevalensi Penyakit Karang Di Winward Dan Leeward Pulau Pari, Kepulauan Seribu, Jakarta. Jurnal Prosiding Forum Inovasi Teknologi Akuakultur. 1089 - 1094.

Malay, F. N. 2000. Analisis Ekonomi Terumbu Karang (study Kasus di Kawasan kelurahan Pulau Kelapa), Taman Nasional Laut Kepulauan Seribu. DKI Jakarta.

Mazni, $\quad$ R. 2008. Uji Aktivitas Antibakteri Ekstrak Etanol Umbi Bidara Upas (Meremia Mammosa Chois) Terhadap Staphylococcus Ureus dan Escheriachia Coli Serta Brine Shrimp Letnality Test. Skripsi. Fakultas Farmasi. Universitas Muhammadiyah Surakarta. Surakarta.

Mellani, N. P. F., Hendrawan, I. W., dan Karim, W. 2019. Kondisi Kesehatan Karang Genus Porites di Perairan Jemelukdan Penuktukan-Bali. Journal of Marine and Aquatic Sciences. 5(1): 29-35.

Nugraha, W.A., M. Efendy., Insafitri., F. M. Huda. 2008. Karakteristik Penyakit White Band Disease Dan White Syndrome Secara Visual Dan Histologi Pada Karang Acropora Sp. Dari Pulau Gili Labak Sumenep Madura. Jurnal Ilmu Kelautan Tropis. 10(3) : 711-718.

Nybakken, W. J. 1988. Biologi Laut. Suatu Pendekatan Ekologis. Gramedia, Jakarta : 459 hal.

Potter, P. A dan Perry, A. G. 2005. Fundamentals of Nursing. 6th ed., Mosby, St. Louis, 426-430.

Rani,C. 2003. Perikanan Dan Terumbu Karang Rusak: Bagaimana Mengelolanya?. Jurnal bionatura. 5(2) : 97-111.

Raymundo, L. J., Couch, C. S. and Harvell, C. D. 2008. Coral Disease Handbook: Guidelines for Assessment, Monitoring \& Management. Coral Reef Targeted Research and Capacity Building for Management Program. The University of Queensland. Australia.

Renta, P. P., Purnama, D., Negara, B. F. S. P., Rahmantyo, D. A. Y., Adhi, N. D., Siagian, R. A. S., Kusuma, A. B. 2020. Prevalensi dan Jenis Penyakit yang Menginfeksi Karang di Perairan Pulau Enggano Bengkulu. Jurnal Enggano. 5(1): 101 - 112.

Richardson, L. L. 1998. Coral diseases: What is really known?. Trends in Ecology and Evolution. 13(11): 438-443.

Riyantini I. 2008. Pelestarian Ekosistem Terumbu Karang Sebagai Upaya Konservasi. Makalah disajikan pada Ceramah IImiah "Padjajaran Diving Club". FPIK. Bandung. 
Rosenberg, E., Loya, Y., Sulam, R., dan Barash, Y. 2005. Bacterial Strain BA-3 and a filterable factor cause awhite plague-like disease in corals from the Eilatcoral reef. Aquatic Microbial Ecology. 40: 183-189.

Rosyid, A. dan Luthfi, O. M. 2018. Pengamatan Laju Penyakit White Syndrome Pada Montipora sp. Di Pulau Pramuka, Taman Nasional Laut Kepulauan Seribu, DKI Jakarta. Journal of Marine and Aquatic Sciences. 5(2): 22-28.

Santoso, D. A dan Kardono. 2008. Teknologi Konservasi Dan Rehabilitasi Terumbum Karang. Jurnal Teknik lingkungan. 9(3) : 121 - 226.

Stedman. 2000. The significance of coral disease epizootiology for coral reef conservation. Journal Biological Conservatiom. 96 : 347 - 361.

Suharsono. 2008. Jenis-Jenis Karang yang Umum di Jumpai di Indonesia. LIPI-P3O Proyek Penilitian dan Pengembangan Daerah, Jakarta

Sunagawa, S., Desantis, T. Z., Piceno, Y. M., Brodie, E. L., Desalvo, M. K., Voolstra, C. R. 2009. Keragaman bakteri dan perubahan komunitas terkait penyakit wabah putih di karang Karibia Montastraea faveolata. ISME J. 131 : 512-521.

Supriharyono. 2007. Pengelolaan Ekosistem Terumbu Karang. Djambatan. Jakarta. 118 hal.

Sutherland K, Porter J. W, Cecilia T. 2004. Disease andimmunity in Caribbean and Indo-Pacific zooxanthellate corals. Marine Ecol Prog Ser. 266: 273- 302.

Veron J. E. N. 2000. Coral of The World Australian Institute of Marine Science. Townsville.

Wijaya, C. K., R. Komala., dan Giyanto. 2017. Kondisi, Keanekaragaman Dan Bentuk Pertumbuhan Karang Di Pulau Kayu Angin, Kepulauan Seribu.

Yamashiro, H. 2004. Coral disease. Coral Reef of Japan. Edited by The Japanese Coral Reef Society and Ministry of the Environment. Ministry of the Environment of Japan, 356 pp. 